\title{
Interrelationships Between Pelagic Fishes and Plankton in the Coastal Fishing Ground of the Southwestern Japan Sea
}

\author{
Y. Ogawa and T. Nakahara \\ Yamaguchi Prefectural Open-Sea Fisheries Experimental Station, Ootomari, Senzaki, Nagato-shi, Japan
}

\begin{abstract}
Interrelationships between the occurrences of pelagic fishes and plankton in coastal fishing grounds have been studied, in two phases, in coastal waters close to Esaki, southwestern Japan Sea, from April through Decernber, 1970. The first phase comprised a general investigation of seasonal changes in the occurrences of plankton and pelagic fishes; the second phase, of an examination of the interrelationships between distribution of pelagic fishes and zooplankton. The results reveal complicated interrelations. For pelagic fishes, the distribution of copepods, their major prey, seems to be of paramount importance. The fishes appeared primarily in close vicinity to dense copepod populations. High aggregations of Noctiluca scintillans or cladoceran species exerted unfavorable effects on the fishes, even in the presence of copepods. Apparent interrelationships were also established in regard to seasonal abundance changes of plankton and pelagic fishes. The results obtained differ somewhat from known prey-predator oscillations postulated by theoretical equations. Alternations in water masses are suggested to act as significant modifying influences.
\end{abstract}

\section{INTRODUCTION}

The effects of abiotic environmental factors on marine organisms have received detailed attention in Volume I of 'Marine Ecology' (Kinne, 1970, 1971, 1972). Biotic factors have attracted much less attention (e.g. 'Marine Ecology', Volume IV, Kinne, 1978). However, there is ample evidence that biotic factors can exert important, if not decisive, influence. In particular, the interrelations between fishes and other marine organisms require more attention. According to Harvey (1950), the biomass of pelagic fishes in the English Channel approximately parallels that of the zooplankton. Although there is not a simple chain from phytoplankton through herbivorous zooplankton to fishes, the prey-predator relations are of basic significance in marine food webs. Riley (1963) noted that the relationship appeared to be non-linear even in the clear correlations established by Sette (1955) for phosphate, zooplankton and tuna in the tropical Pacific Ocean. The importance of some of the inherent non-linearities present in both physical and biochemical processes in the sea was discussed by Heaps and Adam (1975). In spite of the importance of such studies, little effort has thus far been devoted to the study of the coastal fishing ground in the southwestern Japan Sea.

\section{MATERIAL AND METHODS}

The fishing ground north of Esaki centers at about $34^{\circ} 45^{\prime} \mathrm{N}, 131^{\circ} 35^{\prime} \mathrm{E}$. A fishing ground for a small purse seiner is maintained within a radius of about 5 nautical miles. The catch landed by 11 small purse seiners at Esaki port was about 2,320 tons from May to November, 1970. The most dominant species landed was anchovy Engraulis japonica, comprising 50\%, The remaining percentages were accounted for by horse mackerel Trachurus japonicus, mackerel Scomber japonicus, round herring Etrumeus micropus and sardine Sardinops melanosticta. The size of the fishing ground seems to be suitable as a model case, taking the capacity of R. V. 'Wakashio-maru' (22 gross tons) into consideration. Moreover, cooperation with local fishermen was possible. The data on landings of pelagic fishes are based on their daily logbooks.

The following observations were conducted with $\mathrm{R}$. $\mathrm{V}$. 'Wakashio-maru' :(1) monthly samplings of seasonal changes in hydrographic conditions and plankton occurrence at two stations (Fig. 1); (2) analysis of interrelations between pelagic fishes and zooplankters based on horizontal distributions. While investigations were carried out in June, August and October at 16 stations (Fig. 1), only two examples are presented in 


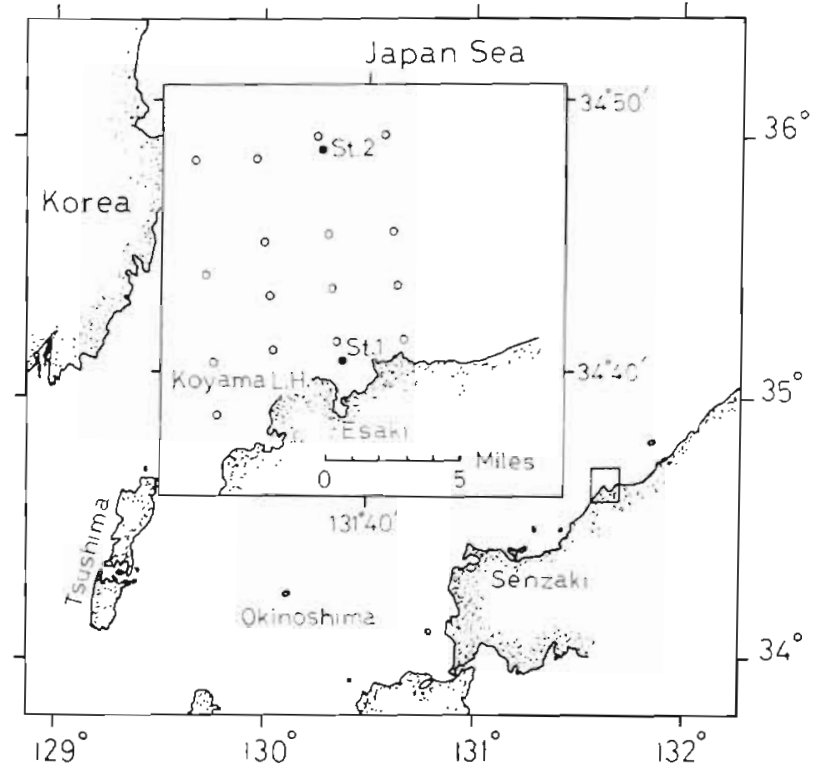

Fig. 1. Location of standard stations. Solid circles: monthly stations of plankton and hydrographic samplings. Open circles: stations where plankton tows were carried out in June, August and October

this paper. Pelagic fish populations on the fishing ground were measured by the acoustic method. The fishfinder (FURUNO, F-812B) was employed at a frequency of $22 \mathrm{KHz}$. After each cruise, fish population abundances were determined on the basis of echo traces on echograms. An index of fish population size was obtained as 'school count' by multiplying the height of the echo trace by its width. Also random samplings of fishes caught were made for obtaining authentic information about sizes of the fishes appearing in the fishing ground during acoustic surveys.

Vertical zooplankton tows were made with a Marunaka net $(60 \mathrm{~cm}$ mouth diameter, $160 \mathrm{~cm}$ length, made of nylon bolting cloth with $0.328 \mathrm{~mm}$ mesh opening) from the sea bottom to the surface. Although a flowmeter was not employed for net tows, rough estimates of relative abundance of zooplankton were made assuming the filtration efficiency of the net to be $100 \%$ in such a shallow tow. Phytoplankton was sampled with a Kitahara sampling bottle at depths of $0.5,5$, $10,20,30$, and $50 \mathrm{~m}$. Zooplankton and phytoplankton samples were preserved in formalin. Each of the samples was poured into glass cylinders and allowed to settle for $24 \mathrm{~h}$ in the laboratory. Part of the samples was then used for counting. Taxonomic identification was obtained to species or genus. Copepod nauplii were sampled in considerable quantity with the Kitahara sampling bottle; hence, individual numbers of nauplii were counted. Temperature and salinity were measured at each station.

Because of bad weather conditions in winter, the observations were restricted to the period from April through December. Accordingly the term 'seasonal change' refers here to changes observed during the fishing season.

\section{RESULTS}

\section{Seasonal Changes in Hydrography}

The major current in the Japan Sea is the Tsushima Current, a branch of the Kuroshio (Suda et al., 1932; Uda, 1934; Lim, 1971). The Japan Sea coast is located south of this eastward current and decisively influenced by the Tsushima Current. This current is commonly characterized by relatively warm and saline water, although low-salinity water termed 'Upper Water of the Tsushima Current' occurs during summer (Miyazaki, 1953; Yasui et al., 1967). The Japan Sea is characterized by tides of extremely small range

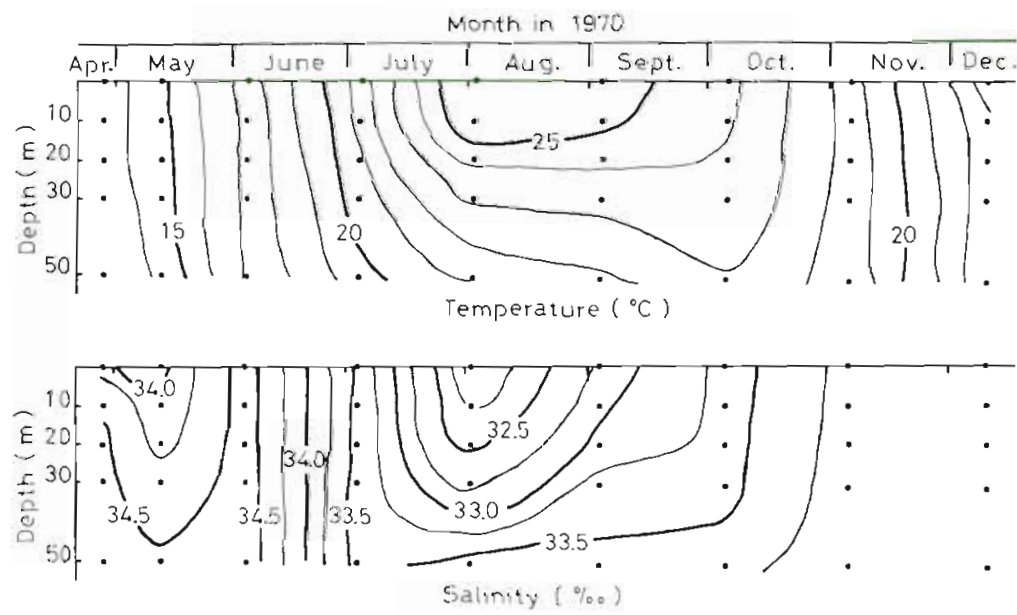

Fig. 2. Isopleths of water temperature $\left({ }^{\circ} \mathrm{C}\right.$ ) and salinity $(\%)$ at Station 1 (sounding $54 \mathrm{~m}$ ). Typical seasonal changes on the fishing ground 
(Ogura, 1933); current velocities remain low, rarely exceeding 2.0 knots.

Isopleths of water temperature and salinity are shown in Figure 2, illustrating a typical example of seasonal changes in hydrographic conditions of the fishing ground based on data obtained at Station 1. The horizontal temperature range at each standard depth was up to $3 \mathrm{C}^{\circ}$; no significant horizontal temperature gradient was found. However, there are conspicuous vertical temperature gradients during summer. The seasonal thermocline began to appear in July and to disappear in October after attaining a maximum lasting from late July through early September. Corresponding to the development of the seasonal thermocline, low-salinity water appeared after late June and the lowest salinity occurred in early August. Although low-salinity water (below $34.1 \%$ ) was also observed temporarily in May, it seems to result from local river outflow. Except for such temporary variation, the hydrographic conditions followed almost the same seasonal changes as those reported for the Tsushima Current by Koshimizu (1958) and Nan-niti and Fujiki (1967). The fishing ground studied is sea- sonally occupied by two quite different water masses: high-temperature - low-salinity water during July to October, and low-temperature - high-salinity water from November through June. It is evident that such alternations in water masses reflect fluctuations of the Tsushima Current.

\section{Seasonal Changes in Phytoplankton Occurrence}

Seasonal changes in phytoplankton occurrence during the fishing season are shown in Figure 3 . Before August, total cell counts showed considerable variations from month to month, even between depths sampled within the same month. In contrast, variations were slight after September. On an average, seasonal changes in total cell counts reveal three peaks: in May, from July to August, and in October. Between the two stations, differences in variations were noticeable at a shallower depths. Cell counts tended to be higher at the inshore station (St. 1) than at the offshore station (St. 2) where the summer peak was less pronounced. The shallower the depth, the wider tended to be the

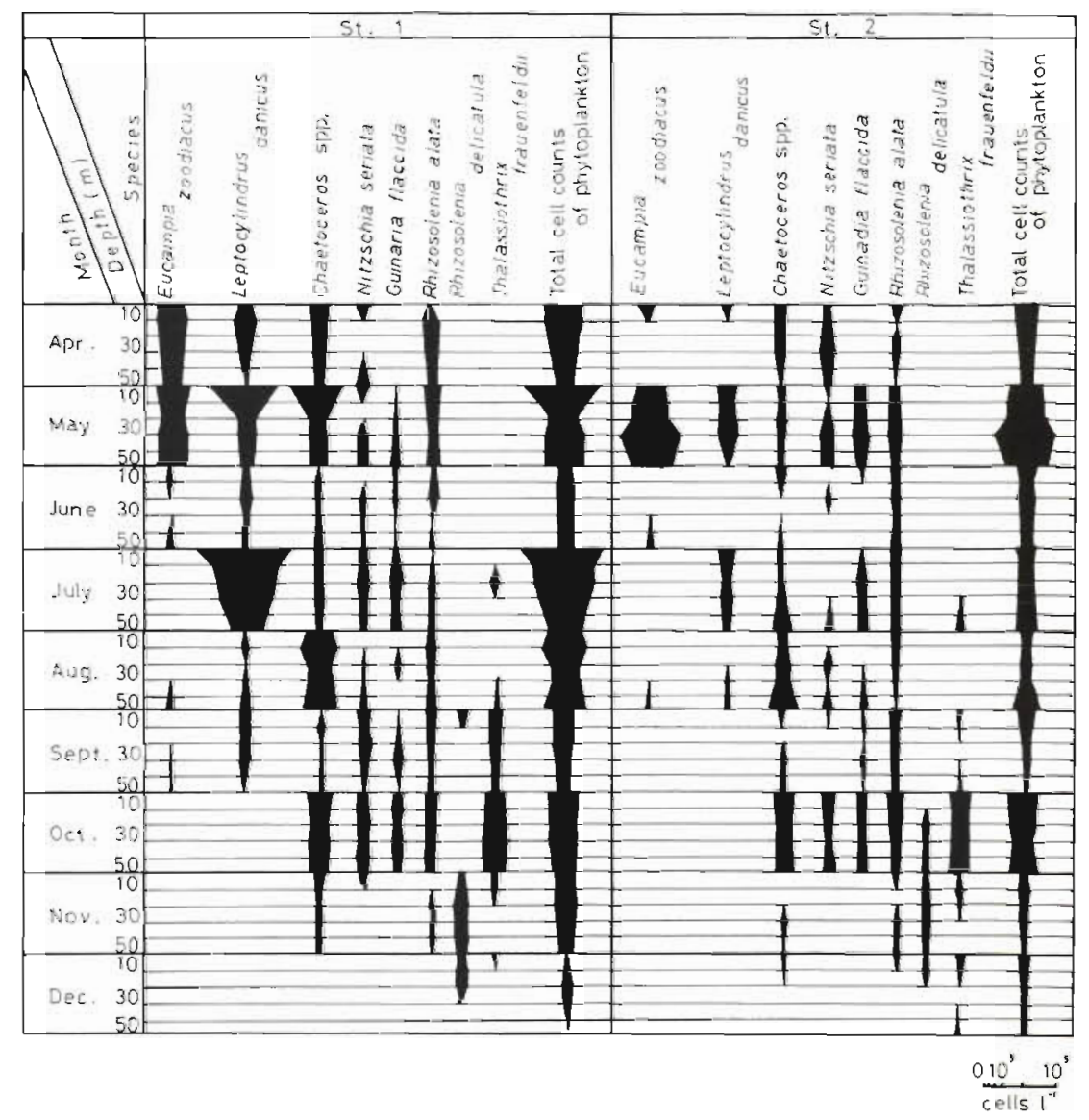

Fig. 3. Seasonal occurrence of dominant phytoplankters, expressed as cube root of cell counts $1^{-1}$; based on monthly samplings with Kitahara bottle at Stations 1 and 2 
variation. At $50 \mathrm{~m}$ depth, however, seasonal changes showed almost identical patterns at both stations.

The highest cell count amounted to $2.2 \times 10^{5}$ cells $1^{-1}$ at $0.5 \mathrm{~m}$ of Station 1 in July; the lowest, 15 cells $1^{-1}$, occurred at $20 \mathrm{~m}$ of Station 2 in December. At Station 1, Leptocylindrus danicus was dominant totaling $99.8 \%$. Large cell counts seemed to prevail in the presence of a dominant species. No dominant species was noticed when the cell counts remained under $2 \times 10^{3}$ cells $1^{-1}$. Accordingly, the peak indicates a noticeable tendency: from spring to summer, only one species seems to take an important part in peak formation; in the autumn peak, two or more dominant species were identified. For instance, at Station 1, the peaks in May and July are based on Leptocylindrus danicus and the May peak at $30 \mathrm{~m}$ of Station 2 on Eucampia zoodiacus. On the other hand, the October peak at Station 2 resulted from almost equal contributions by Thalassiothrix frauenfeldii and Chaetoceros spp. A few dominant species seem to affect the variation in the total cell counts in autumn.

\section{Seasonal Changes in Occurrences of Pelagic Fishes and Zooplankters}

The seasonal changes in zooplankton occurrence at the two stations are shown in Fig. 4 and Table 1. The volume of zooplankton settled over $24 \mathrm{~h}$ indicates notable variations, but shows a significant peak in spring as well as another lower peak in autumn following the depression in summer. In spring, some Thaliacea species (Muggiaea sp., Diphyes sp., Salpa fusiformis, Iasis zonaria and Doliolum sp.) were abundant and caused the peak. Fairly large numbers of Noctiluca scintillans and Penilia avirostris were also noticed during spring and summer. Although copepods did not always dominate, they contribute an important food item for pelagic fishes. Copepods are well-known as favorite prey for pelagic fishes (e.g. Yamashita, 1957; Yasuda, 1960; Kinne, 1977, p. 979).

Seasonal changes in total individual copepod numbers showed two peaks, in spring and autumn, aver-
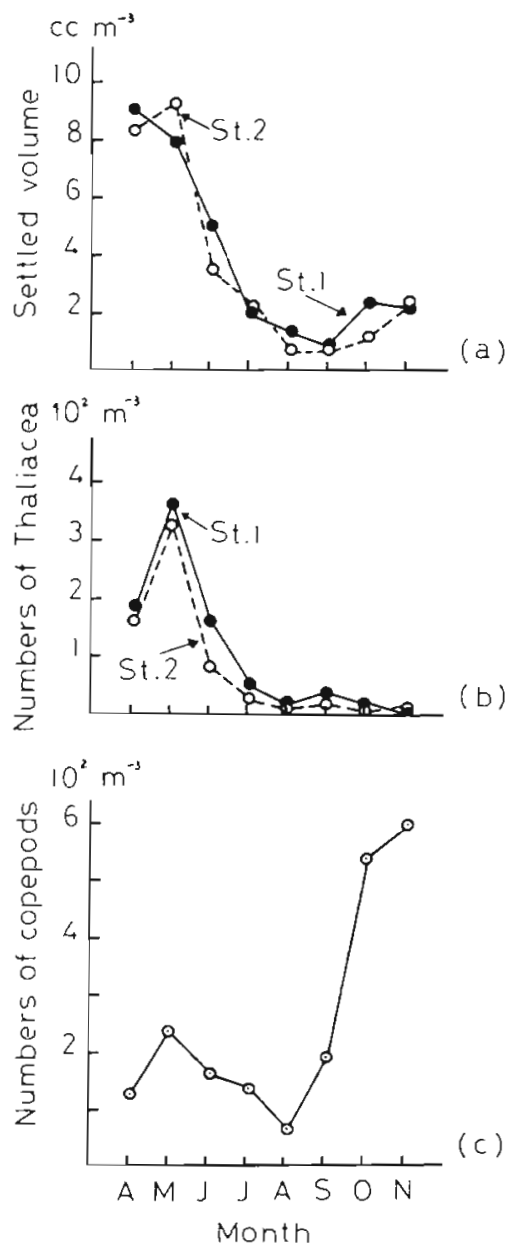

Fig. 4. Seasonal occurrence of zooplankton; monthly averages; samplings with Marunaka net at Stations 1 and 2. (a) Settled volume for $24 \mathrm{~h}\left(\mathrm{cc} \mathrm{m}^{-3}\right)$; (b) individual numbers of Thaliacea $\mathrm{m}^{-3}$; (c) individual numbers of copepods $\mathrm{m}^{-3}$

Table 1. Seasonal occurrence of pelagic fishes and plankters. Fish-catch data derived from operational logbooks of purse seiners at Esaki (Japan) on days before and after plankton samplings

\begin{tabular}{|c|c|c|c|c|c|c|c|c|c|c|c|c|}
\hline \multirow{2}{*}{ Month } & \multirow{2}{*}{$\begin{array}{l}\text { Phyto- } \\
\text { plankton } \\
\left(\text { No. } l^{-1}\right)\end{array}$} & \multirow{2}{*}{$\begin{array}{l}\text { Settled } \\
\text { volume } \\
\left(\mathrm{cc} \mathrm{m} \mathrm{m}^{-3}\right)\end{array}$} & \multicolumn{5}{|c|}{ Zooplankton (No. $\mathrm{m}^{-3}$ ) } & \multirow{2}{*}{$\begin{array}{c}\text { Effort } \\
\text { (hauls) }\end{array}$} & \multicolumn{4}{|c|}{ CPUE of purse seiners (tons) } \\
\hline & & & $\begin{array}{l}\text { Cope- } \\
\text { pods }\end{array}$ & $\begin{array}{c}\text { Copepod } \\
\text { nauplii }\end{array}$ & $\begin{array}{l}\text { Sagitta } \\
\text { spp. }\end{array}$ & $\begin{array}{l}\text { Tha- } \\
\text { liacea }\end{array}$ & $\begin{array}{l}\text { Noctiluca } \\
\text { scintillans }\end{array}$ & & Total & $\begin{array}{l}\text { An- } \\
\text { chovy }\end{array}$ & $\begin{array}{l}\text { Horse } \\
\text { mackerel }\end{array}$ & Mackerel \\
\hline April & 5,074 & 8.67 & 128 & $12\left(\times 10^{3}\right)$ & 5 & 148 & 31 & 0 & \multicolumn{4}{|c|}{ (out of fishing season) } \\
\hline May & 32,445 & 8.47 & 239 & 15 & 11 & 272 & 2,382 & 6 & 1.22 & 1.19 & 0.03 & 0 \\
\hline June & 395 & 4.31 & 163 & 9 & 22 & 101 & 2,695 & 13 & 0.83 & 0.01 & 0.82 & 0 \\
\hline July & 33,800 & 2.04 & 137 & 4 & 29 & 32 & 1,694 & 21 & 0.78 & 0.05 & 0.73 & 0 \\
\hline August & 5,741 & 0.93 & 63 & 5 & 21 & 3 & 954 & 21 & 0.28 & 0.03 & 0.25 & 0 \\
\hline September & 474 & 0.67 & 187 & 13 & 18 & 19 & 106 & 22 & 1.08 & 0.82 & 0 & 0.26 \\
\hline October & 5,638 & 1.81 & 540 & 21 & 50 & 2 & 0 & 20 & 2,02 & 1.87 & 0 & 0.15 \\
\hline November & 621 & 2.19 & 620 & 12 & 44 & 1 & 0 & 7 & 1.51 & 0 & 0.60 & 0.91 \\
\hline December & 72 & - & - & 6 & - & - & - & 0 & \multicolumn{4}{|c|}{ (out of fishing season) } \\
\hline
\end{tabular}


ages of the two stations. Species of Paracalanus, Clausocalanus, Oncaea, Corycaeus and Oithona were fairly dominant throughout the fishing season. Calanus helgolandicus appeared mainly in spring, while Temora spp. and other Calanus species appeared only after summer. Species of Candacia, Acartia and Eucalanus occurred in small numbers, though they were present throughout the season. The seasonal occurrence of copepod nauplii also reveals two peaks in spring and autumn corresponding to those of adult copepods (Fig. 5 and Table 1).

Seasonal changes in the occurrences of pelagic fishes (Fig. 6 and Table 1) are based on catch data from operational logbooks of 11 purse seiners at Esaki. Catch data on the day before and after the plankton samplings were used. Sequential changes in the catch

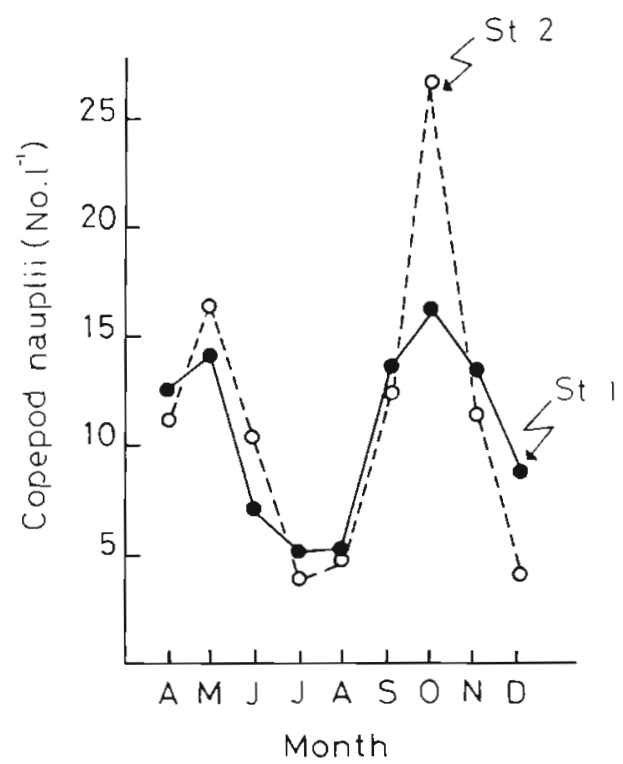

Fig. 5. Seasonal changes in abundance of copepod nauplii (No. $1^{-1}$ ); based on monthly samplings with Kitahara bottle at Stations 1 and 2 per unit effort almost parallel the pattern of copepod and nauplii abundances. There exists a tendency in pelagic fish abundance to increase with copepod abundance in spring and autumn; fish abundance is low when copepods are scarce in summer. The seasonal occurrence of pelagic fishes also suggests that anchovy were numerous when other fishes, horse mackerel and mackerel, were few and vice versa. These relationships are summarized in Table 2 .

Table 2 reveals a positive, significant correlation between fishes and copepods or nauplii. Concerning the correlations calculated, it was found that a positive correlation might occur between species of Sagitta and copepod nauplii, implying a prey-predator relation-

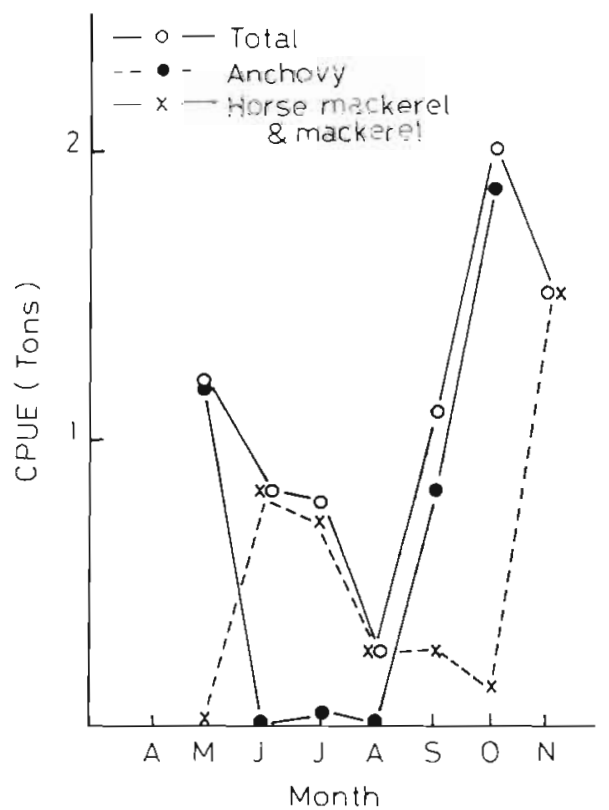

Fig. 6. Seasonal changes in occurrence of pelagic fishes on the coastal fishing ground north of Esaki, expressed as catch per unit effort (CPUE)

Table 2. Seasonal dynamics of pelagic fishes and plankter abundances. Numbers represent correlation coefficients calculated from Table 1 . Underlined are coefficients significant at the $90 \%$ level or more. CPUE: Catch per unit effort

\begin{tabular}{|c|c|c|c|c|c|c|c|c|c|c|}
\hline Parameter & $\begin{array}{l}\text { Phyto- } \\
\text { plank- } \\
\text { ton }\end{array}$ & $\begin{array}{c}\text { Settled } \\
\text { zooplankton } \\
\text { volume }\end{array}$ & $\begin{array}{l}\text { Cope- } \\
\text { pods }\end{array}$ & $\begin{array}{l}\text { Copepod } \\
\text { nauplii }\end{array}$ & $\begin{array}{l}\text { Sagitta } \\
\text { spp. }\end{array}$ & $\begin{array}{c}\text { Thalia- } \\
\text { cea }\end{array}$ & $\begin{array}{l}\text { Noctiluca } \\
\text { scintillans }\end{array}$ & $\begin{array}{l}\text { CPUE of } \\
\text { total } \\
\text { catch }\end{array}$ & $\begin{array}{c}\text { CPUE } \\
\text { of } \\
\text { anchovy }\end{array}$ & $\begin{array}{l}\text { CPUE of horse } \\
\text { mackerel and } \\
\text { mackerel }\end{array}$ \\
\hline Phytoplankton & & 0.31 & -0.24 & -0.10 & -0.19 & 0.48 & 0.52 & -0.12 & 0.09 & -0.27 \\
\hline $\begin{array}{l}\text { Settled zooplankton } \\
\text { volume }\end{array}$ & & & -0.19 & -0.19 & -0.62 & $\underline{0.91}$ & 0.36 & 0.10 & 0.21 & -0.21 \\
\hline Copepods & & & & 0.64 & $\underline{0.80}$ & -0.28 & -0.44 & $\underline{0.82}$ & 0.36 & 0.41 \\
\hline Copepod nauplii & & & & & 0.30 & 0.17 & -0.37 & 0.89 & 0.88 & -0.30 \\
\hline Sagitta spp. & & & & & & 0.26 & -0.32 & $\overline{0.67}$ & $-\overline{0.28}$ & 0.42 \\
\hline Thaliacea & & & & & & & 0.54 & -0.02 & 0.22 & -0.34 \\
\hline Noctiluca scintillans & & & & & & & & -0.46 & -0.26 & -0.11 \\
\hline CPUE of total catch & & & & & & & & & 0.71 & -0.13 \\
\hline CPUE of anchovy & & & & & & & & & & -0.66 \\
\hline CPUE of horse macke & erel and & mackerel & & & & & & & & \\
\hline
\end{tabular}



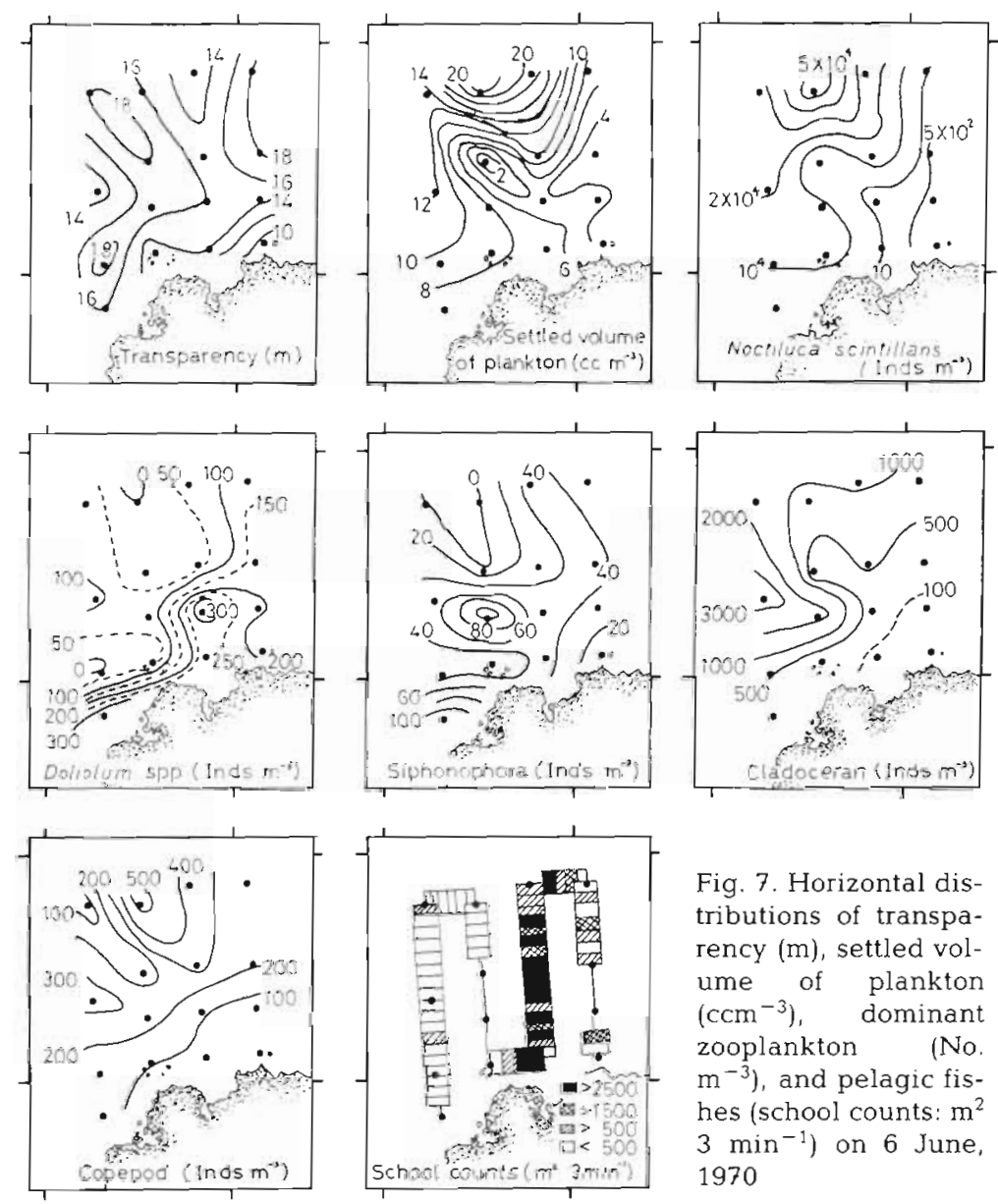

Fig. 7. Horizontal distributions of transparency $(\mathrm{m})$, settled volume of plankton $\left(\mathrm{cm}^{-3}\right)$, dominant zooplankton (No. $\left.\mathrm{m}^{-3}\right)$, and pelagic fishes (school counts: $\mathrm{m}^{2}$ $\left.3 \mathrm{~min}^{-1}\right)$ on 6 June, 1970

ship. While the negative correlation between anchovy and other fishes attains significance only when lowering the confidence limit below $90 \%$.

\section{Relationships Between Pelagic Fishes and Zooplankters}

Horizontal distributions of the pelagic fishes on the fishing ground and distributions of dominant zooplankters are shown in Figures 7 and 8 . Figure 7 illustrates distributions during the rich-haul season; Figure 8 represents conditions during the poor-haul season of purse seiners as suggested by Figure 6. School counts were summed up every $3 \mathrm{~min}$ for representation in the figures. Random samplings of fishes landed reveal that fish species appear, during plankton samplings as follows: (1) the haul in June was dominated by horse mackerel of $6.7 \mathrm{~cm}$ in mean body length; (2) the haul in August consisted mainly of anchovy reaching up to $7.1 \mathrm{~cm}$.

During spring, Noctiluca scintillans and some cladoceran species (mainly Penilia avirostris) were abundant. In areas where these species occurred abundantly, few fishes seemed to be present. The fishes also appeared to be low in number in areas where settled

Table 3. Quantitative relationships between pelagic fishes and zooplankters in the spatial distributions shown in Figure 7

\begin{tabular}{|c|c|c|c|c|c|c|}
\hline $\begin{array}{l}\text { Ranges of school } \\
\text { counts }\left(\mathrm{m}^{2}\right)\end{array}$ & $\begin{array}{l}\text { Settled volume } \\
\left(\mathrm{cc} \mathrm{m} \mathrm{m}^{-3}\right)\end{array}$ & $\begin{array}{l}\text { Noctiluca } \\
\text { spp. }\end{array}$ & $\begin{array}{c}\text { Cladocera } \\
(\text { mean } \pm 2 \sigma / \sqrt{n})\end{array}$ & Copepods & $\begin{array}{l}\text { Doliolum } \\
\text { spp. }\end{array}$ & $\begin{array}{l}\text { Siphonophora } \\
\left(\text { No. } \mathrm{m}^{-3}\right)\end{array}$ \\
\hline $\mathrm{S}=0$ & $4.60 \pm 0.69$ & $5.755 \pm 1,639$ & $759 \pm 244$ & $148 \pm 20$ & $108 \pm 31$ & $54 \pm 12$ \\
\hline $500 \geq S>0$ & $11.91 \pm 1.52$ & $22,012 \pm 4.415$ & $1.339 \pm 285$ & $246 \pm 38$ & $82 \pm 21$ & $24 \pm 5$ \\
\hline $1,500 \geq S>500$ & $11.71 \pm 3.11$ & $12,878 \pm 4.829$ & $797 \pm 303$ & $229 \pm 56$ & $143 \pm 46$ & $36 \pm 8$ \\
\hline $2,500 \geq S>1,500$ & $9.06 \pm 3.68$ & $8,492 \pm 7,171$ & $553 \pm 293$ & $222 \pm 97$ & $148 \pm 84$ & $36 \pm 3$ \\
\hline $\mathrm{S}>2,500$ & $10.59 \pm 2.97$ & $10,582 \pm 3,971$ & $447 \pm 176$ & $229 \pm 48$ & $170 \pm 55$ & $39 \pm 3$ \\
\hline
\end{tabular}



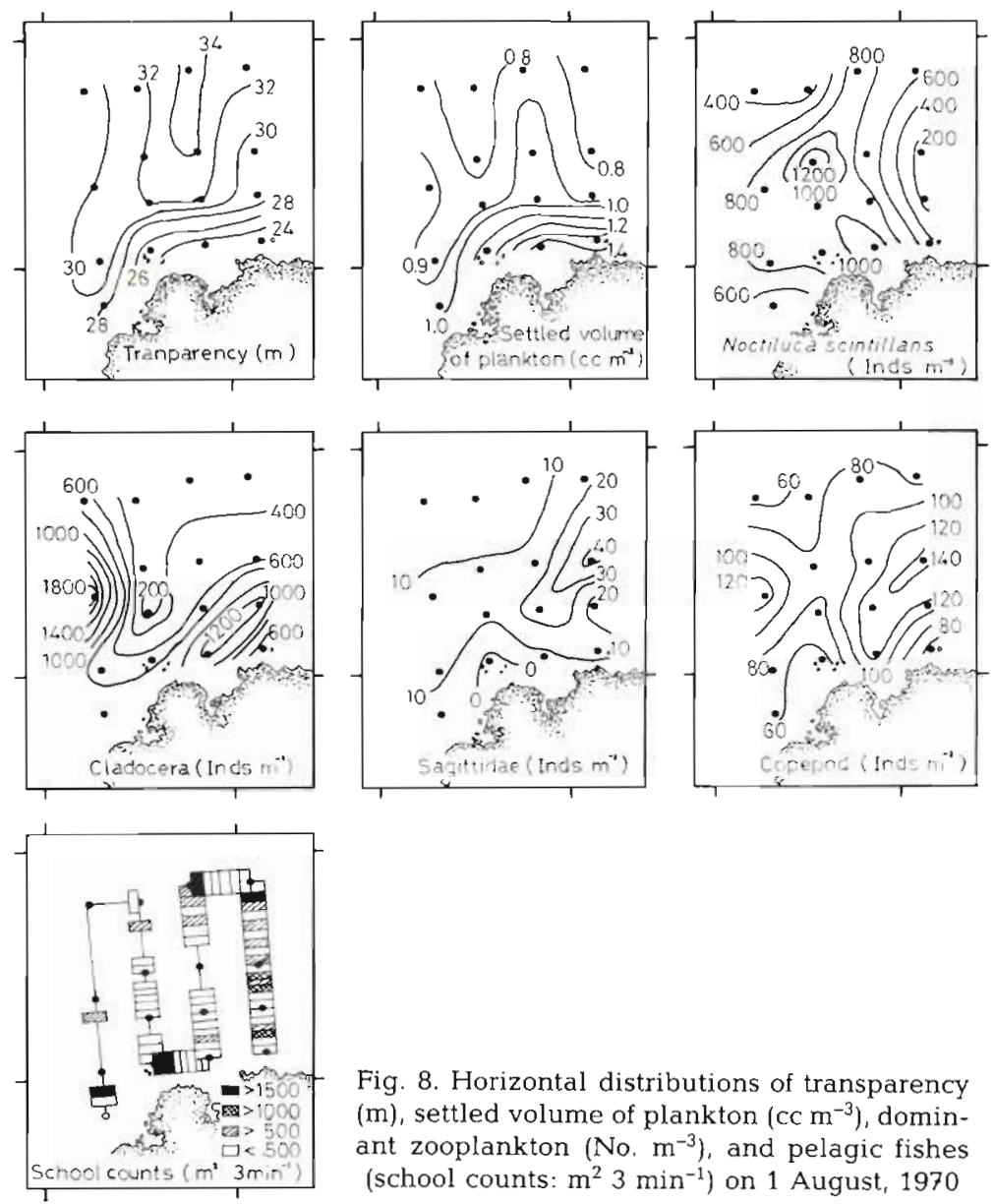

Fig. 8. Horizontal distributions of transparency (m), settled volume of plankton $\left(\mathrm{cc} \mathrm{m}^{-3}\right)$, dominant zooplankton (No. $\mathrm{m}^{-3}$ ), and pelagic fishes (school counts: $\mathrm{m}^{2} 3 \mathrm{~min}^{-1}$ ) on 1 August, 1970

volume of plankton was poor. In spring, there appeared a tendency among Noctiluca scintillans, cladocerans and Doliolum spp. that one of these attained high abundance values where the others remained few in numbers, implying distributional segregation. However, fairly large numbers of copepods were sampled even where Noctiluca scintillans and cladocerans were abundant; the quantitative relationship between these components is not clear. Some Sagittidae were distributed in accordance with the appearance of copepods during summer and autumn. These data show that (1) large fish counts occur in areas of large copepod counts; (2) fish abundance is low in areas where Noctiluca scintillans and cladocerans are abundant (Table 3). Summer and autumn data, however, did not reveal statistically significant relations. This fact implies that the relations mentioned become obscure at low abundance levels of fishes or plankters.

\section{DISCUSSION}

In the present study, stomach contents of the fishes caught by purse seiners were not investigated because electric lights are always used during fishing operation, and thus many plankters are attracted together with the fishes. Fishes hauled with nets frequently swallow the plankters notwithstanding whether or not they nomally feed on them. In terms of general distributions, the fishes aggregated in close vicinity to copepod patches, except in areas where the copepods occurred together with high aggregations of Noctiluca scintillans or cladocerans which may result in unfavorable feeding conditions for fishes (Figs. 7 and 8 ; Table 3). This fact indicates that copepods constitute an important food item for the fishes studied.

Another relationship between fishes and plankton was also recognized, as indicated by the relation between Noctiluca scintillans or cladocerans and fishes (Figs. 7 and 8 ; Table 3 ). This fact probably indicates competition for space. Furthermore, fish species tend to compete for food because each species occupies overlapping niches (Yamashita, 1957; Yasuda, 1960). In fact, Figure 6 suggests competition for food among fishes, although the negative correlation coefficient calculated was significant only at the $85 \%$ confidence level (Table 2). However, the term 'competition' should be used carefully (Elton, 1958). 
The quantitative relations between phyto- and zooplankton remain difficult to interpret in overall terms (Figs. 3, 4 and 6). It is generally expected that an increase in prey quantity leads to an enlargement of the number of predators, which in turn reduce the net rate of growth of the prey until the latter begins to decline (e.g. Riley, 1946, 1947a, 1947b; Volterra, 1928). The present results are, however, somewhat different from the usual prey-predator oscillations. While phytoplankton cell counts indicate three peaks, the zooplankton abundance reveals only two peaks (Figs. 3 and 4). No summer slack was observed in phytoplankton occurrence. Although the seasonal cycle of phytoplankton observed is somewhat different from a pattern reported from the Japan Sea (Heinrich, 1962), a pattern similar to the present example was found in Pacific coastal waters (Asaoka, 1955). Thus, an increase in diatoms occurs three times a year. Although there is a possibility that the summer peak of phytoplankton accompanied the decline of zooplankton during this period, it is difficult to determine the reason why the zooplankton decreased in summer. The amount of pelagic fishes diminished simultaneously (Fig. 6).

Thus, the phenomena observed do not always agree with the pattern postulated theoretically since Volterra (1928). With respect to this point, Steele (1961) pointed out that the relationship simply appears to be a poor correlation with random scatter. The difficulties, however, may depend in part on fundamental assumptions for developing the theoretical equations. Although all descriptions based on these equations are concerned with sequential time changes in populations of a given water mass, the water masses actually change successively throughout a year on the present fishing ground (Fig. 2). Regarding the fishing-ground hydrography, it is noteworthy that the fishing season began roughly together with the appearance of low-salinity water. Salinities did not exceed $34.1 \%$ at all depths examined in the upper $50 \mathrm{~m}$, especially in autumn when the richest haul was obtained (Figs 2 and 6).

Acknowledgements. The authors express their deep gratitude to Prof. H. Kawai for his unfailing guidance throughout the course of this study. They are most appreciative to Dr. $M$. Anraku for much valuable advice.

\section{LITERATURE CITED}

Asaoka, O. (1955). On the variation of the condition of plankton diatoms and the sea at a pier on Jogashima Island in the period from March 1952 to May 1953. (Jap.; Engl. abstract.) J. oceanogr. Soc. Japan, 11, 69-74.

Elton, S. C. (1958). The Ecology of Invasion by Animals and Plants, Methuen, London.

Harvey, $\mathrm{H}$. W. (1950). On the production of living matter in the sea off Plymouth. J. mar. Biol. Ass. U. K., 29, 97-137.

Heaps, N. S. and Adam, Y. A. (1975). Modeling of Marine
System, Non-linearities associated with physical and biochemical processes in the sea, Elsevier, New York.

Heinrich, A. K. (1962). The life history of plankton animals and seasonal cycles of plankton communities in the oceans. J. Cons. int. Explor. Mer, 27, 15-24.

Kinne, O. (Ed.) (1970). Marine Ecology, Vol. I, Environmental Factors, Part 1, Wiley, London.

Kinne, O. (Ed.) (1971). Marine Ecology, Vol. I, Environmental Factors, Part 2, Wiley, London.

Kinne, O. (Ed.) (1972). Marine Ecology, Vol. I, Environmental Factors, Part 3, Wiley, London

Kinne, O. (1977). Cultivation of animals: research cultivation In O. Kinne (Ed.), Marine Ecology, Vol. III, Cultivation, Part 2. Wiley, Chichester. pp. 579-1293.

Kinne, O. (Ed.) (1978). Marine Ecology, Vol. IV, Dynamics, Wiley, Chichester.

Koshimizu, N. (1958). The properties of water masses in the district of the Tsushima Current in the Japan Sea. (Jap.; Engl. abstract.) J. oceanogr. Soc. Japan, 23, 99-102.

Lim, D. B. (1971). On the origin of the Tsushima Current water. J. oceanogr. Soc. Korea, 6, 85-91.

Miyazaki, M. (1953). On the water masses of the Japan Sea. (Jap.; Engl. abstract.) Bull. Hokkaido reg. Fish. Res. Lab., 7. $1-65$

Nan-niti, T. and Fujiki, A. (1967). Secular variations of hydrographic conditions in the East Tsushima Straits. (Jap.; Engl. abstract.) J. oceanogr. Soc. Japan, 23, 201-212.

Ogura, S. (1933). The tide in the sea adjacent to Japan. Bull. hydrogr. Dep., Tokyo, 7, 1-189.

Riley, G. A. (1946). Factors controlling phytoplankton population on Georges Bank. J. mar. Res., 6, 54-73.

Riley, G. A. (1947a). A theoretical analysis of the zooplankton population of Georges Bank. J. mar. Res., 6, 104-113.

Riley, G. A. (1947b). Seasonal fluctuations of the phytoplankton population in New England coastal waters. J. Mar. Res., 6, 114-125.

Riley, G. A. (1963). The Sea, Vol. 2, Theory of food-chain relations in the ocean, Interscience Publishers, New York.

Sette, O. A. (1955). Consideration of midocean fish production as related to oceanic circulatory system. J. mar. Res., 14, $398-414$.

Steele, J. H. (1961). Primary production. In M. Sears (Ed.), Oceanography. Am. Ass. Adv. Sci., Washington. pp. 519-538. (Am. Ass. Adv. Sci. Publ., 67, 519-538.)

Suda, K., Hidaka, K., Matsudaira, Y., Kawasaki, H., Kurashige, $H$, and Kubo, $T$. (1932). The results of oceanographical observations on board H. M. S. 'Shumpu Maru' in the principal part of the Japan Sea in the summer of 1930. (Jap.; Engl. abstract.) J. oceanogr., Kobe, 4, 1-173.

Uda, M. (1934). The results of simultaneous oceanographical investigation in the Japan Sea and its adjacent waters in May and Jume, 1932. (Jap.; Engl. summary.) J. imp. Fish. Exp. Stn, Tokyo, 5, 57-190.

Voltera, V. (1928). Variation and fluctuations of the numbers of individuals in animal species living together. J. Cons. int. Explor. Mer, 3, 1-51.

Yamashita, H. (1957). Relationship of food of sardine, jack mackerel, mackerel and so on, in waters adjacent to west Kyushu. (Jap.; Engl. abstract.) Bull. Seikai reg. Fish. Res. Lab., 11, 45-52.

Yasuda, F. (1960). The types of food habits of fishes assured by stomach contents examination. Bull. Jap. Soc. scient. Fish., 26, 653-662.

Yasui, M., Yasuda, T., Tanioka, K. and Shiota, O. (1967). Oceanographic studies of the Japan Sea (1), Water characteristics. Oceanogr. Mag., 19, 177-192.

This paper was presented by Professor M. Anraku; it was accepted for printing on July 3, 1979. 